\title{
Setting the standard for routine asthma consultations: a discussion of the aims, process and outcomes of reviewing people with asthma in primary care
}

\section{*Hilary Pinnocka, Monica Fletcher ${ }^{b}$, Steve Holmesc, Duncan Keeley ${ }^{\mathrm{d}}$, Jane Leyshon ${ }^{\mathrm{e}}$, David Price ${ }^{f}$, Richard Russell ${ }^{g}$, Jenny Versnel ${ }^{\mathrm{h}}$, Bronwen Wagstaffi}

\footnotetext{
a Senior Clinical Research Fellow, Allergy and Respiratory Research Group, Centre of Population Health Sciences: GP Section, University of Edinburgh, Scotland, UK

${ }^{\mathrm{b}}$ Chief Executive, Education for Health, The Athenaeum, Warwick, UK

' General Practitioner, The Park Medical Practice, Shepton Mallet, UK

${ }^{d}$ General Practitioner, The Rycote Practice, East Street, Thame, UK

e Team Leader: Respiratory \& Asthma, Education for Health, The Athenaeum, Warwick, UK

f Professor of Primary Care Respiratory Medicine, Centre of Academic Primary Care, University of Aberdeen; Foresterhill Health Centre, Westburn Road, Aberdeen, Scotland, UK

${ }^{9}$ Honorary Clinical Senior Lecturer at the National Heart and Lung Institute, Imperial College, London, UK

${ }^{\mathrm{h}}$ Executive Director of Research and Policy, Asthma UK, London, UK

Policy Advisor, Primary Care Respiratory Society UK, Lockerbie, UK
}

Originally submitted 31st December 2008; resubmitted 15th July 2009; revised version received 8th November 2009; accepted 18th November 2009; online 29th January 2010

\begin{abstract}
Globally, asthma morbidity remains unacceptably high. If outcomes are to be improved, it is crucial that routine review consultations in primary care are performed to a high standard. Key components of a review include:

- Assessment of control using specific morbidity questions to elucidate the presence of symptoms, in conjunction with the frequency of use of short-acting bronchodilators and any recent history of acute attacks

- After consideration of the diagnosis, and an assessment of compliance, inhaler technique, smoking status, triggers, and rhinitis, identification of poor control should result in a step-up of treatment in accordance with evidence-based guideline recommendations

- Discussion should address understanding of the condition, patient-centred management goals and attitudes to regular treatment, and should include personalised self-management education

Regular review of people with asthma coupled with provision of self-management education improves outcomes. Underpinned by a theoretical framework integrating professional reviews and patient self-care we discuss the practical barriers to implementing guided selfmanagement in routine clinical practice.

(C) 2010 Primary Care Respiratory Society UK. All rights reserved.

H Pinnock et al. Prim Care Resp J 2010; 19(1): 75-83.

doi:10.4104/pcrj.2010.00006
\end{abstract}

Keywords asthma, primary care, guided self-management, monitoring long-term conditions, asthma action plan

\section{Introduction: the burden of asthma}

Worldwide, asthma is an important cause of morbidity, economic cost, and mortality. It is estimated that about 300 million people have asthma, with the highest prevalence in the UK, Australasia and North America. ${ }^{1}$ In England, data from general practice suggest that $5.8 \%$ of the population have 'active asthma' (defined as a diagnosis of asthma and a prescription for asthma treatment in the previous 12 months). ${ }^{2}$

Despite the focus in international guidelines on assessing and achieving good disease control in international

\footnotetext{
* Corresponding author: Dr Hilary Pinnock, Allergy and Respiratory Research Group, Centre of Population Health Sciences: GP Section, University of Edinburgh, Doorway 3, Medical School, Teviot Place, Edinburgh, EH8 9AG.

Tel: +44 (0)1316508102 Fax: +44 (0)1316509119 E-mail: hilary.pinnock@ed.ac.uk
} 
guidelines, ${ }^{3}$ surveys have consistently shown unacceptable morbidity associated with low expectations on the part of patients. ${ }^{48}$ It has been estimated that up to three-quarters of the 80,000 admissions for asthma in the UK in 2004 might have been prevented with improved long-term care. ${ }^{9} \mathrm{~A}$ key strategy for reducing the burden of asthma is a shift in emphasis from acute management to long-term care and supported self-management, in order to reduce chronic morbidity and impairment of quality of life, as well as reducing exacerbations, admissions and mortality. ${ }^{3,10}$ Proactive care, with structured reviews provided by clinicians with training in asthma care, improves outcomes. ${ }^{11-15}$

After describing the policy and theoretical framework linking regular reviews and guided self-management, this discussion paper sets out the evidence base supporting the recommended content of good asthma reviews in primary care. It then discusses the role of 'pay-for-performance' exemplified by the UK Quality and Outcomes Framework ${ }^{16}$ as a driver for improving treatment outcomes. An Opinion sheet providing practical guidance for clinicians is available from www.pcrs-uk.org.

\section{Policy and theoretical framework}

The framework for monitoring chronic disease described by Glasziou et al. emphasises the inter-relationship between professional review and patient self-management, ${ }^{17}$ using asthma as an exemplar condition (see Figure 1). Cochrane reviews provide support for this concept, concluding that improved outcomes are the result of training in asthma selfmanagement coupled with regular review. $18-20$ This dual approach is summarised in the GINA asthma guideline as 'guided self-management', 9 is explicitly recommended (Grade A) in the 2008 update of the BTS/SIGN asthma guideline, ${ }^{10}$ and is a core strategy of national programmes to improve asthma care in Finland and Australia. 21,22

Self care is a 'key pillar' of the policy approach to meeting the challenge of providing care for people with long-term

Figure 1. The inter-relationship between professional and self-monitoring (adapted from Glaziou et al..$^{17}$ to illustrate the management and self-management of asthma).

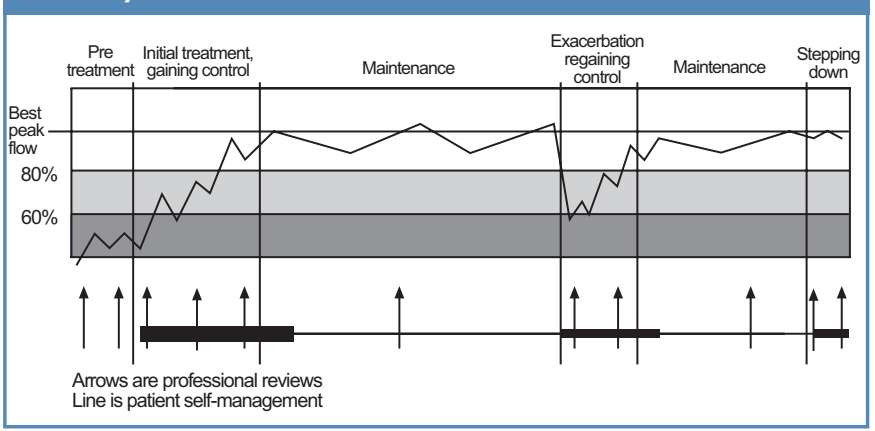

conditions. $^{23-27}$ The widely cited Long-Term Conditions pyramid of care (LTC pyramid) emphases the importance of self-management to "ensure patients and carers have the skills and knowledge they need to understand how to best handle their condition, including how to deal with flare-ups, to adjust medicines, improve their life-styles and access health care services" ${ }^{26}$. Routine reviews operate in the boundary between patient self-care and professional management, ${ }^{28,29}$ not only offering opportunities specifically to reinforce and refine self-management skills, but also more generally to build the trusted relationship valued by patients (see Figure 2). ${ }^{29}$

\section{Asthma reviews}

Asthma reviews in primary care should incorporate three key steps:

1. Assessing control in order to target care appropriately

2. Responding to that assessment by identifying reasons for poor control and adjusting management strategy accordingly

3. Exploring patients' ideas, concerns and expectations, and guiding self-management to facilitate on-going control

\section{Assessing control}

Asthma control reflects the degree to which symptoms are reduced, exacerbations are prevented and normal lung function is maintained by treatment, ${ }^{30}$ with current guidelines defining 'control' as no symptoms, no exacerbations and normal lung function' (see Table 1). Occasional daytime symptoms (defined as less than twice a week) may be consistent with good control, but disturbed sleep due to asthma signals loss of control. Challenge tests for assessment

Figure 2. The long-term condition pyramid with the boundary between professional and self care (adapted from Degeling et al. ${ }^{28}$ ).

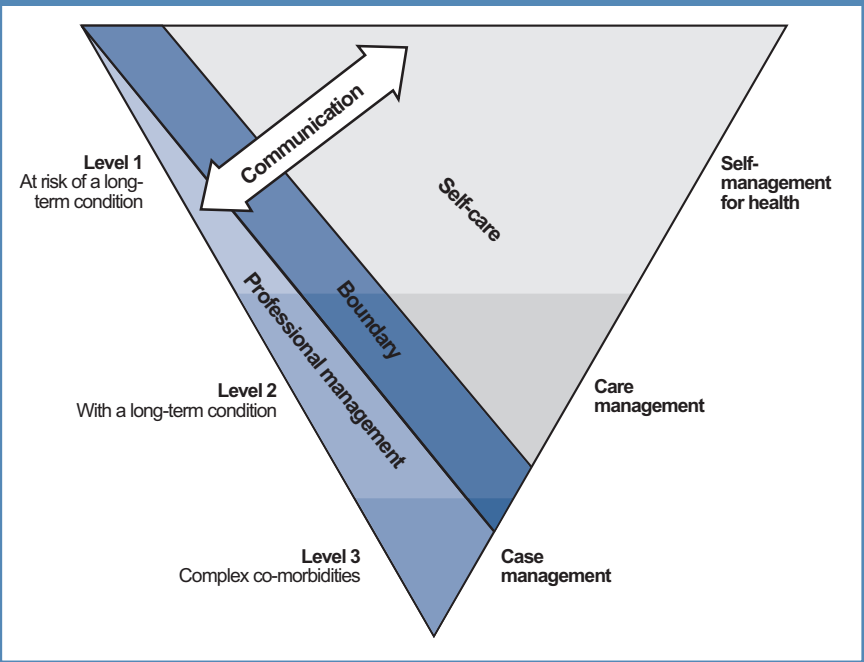




\begin{tabular}{|c|c|c|c|}
\hline Characteristic & $\begin{array}{l}\text { Controlled (All of } \\
\text { the following) }\end{array}$ & $\begin{array}{l}\text { Partly Controlled (Any measure } \\
\text { present in any week) }\end{array}$ & Uncontrolled \\
\hline Daytime symptoms & None (twice or less/week) & More than twice/week & \multirow{5}{*}{$\begin{array}{l}\text { Three or more features } \\
\text { of partly controlled } \\
\text { asthma present in } \\
\text { any week }\end{array}$} \\
\hline Limitations of activities & None & Any & \\
\hline Nocturnal symptoms/awakening & None & Any & \\
\hline Need for reliever/rescue treatment & None (twice or less/week) & More than twice/week & \\
\hline Lung function (PEF or $\left.F E V_{1}\right)^{\mathrm{iii}}$ & Normal & $<80 \%$ predicted or personal best(if known) & \\
\hline Exacerbations & None & One or more/yeari & One in any week ${ }^{i i}$ \\
\hline
\end{tabular}

of bronchial hyper-responsiveness are unlikely to be practical measures of control in primary care settings, though estimation of exhaled nitric oxide as a measure of inflammation may have a place in clinical care in the future. ${ }^{30}$

In primary care, asthma control is normally assessed on the basis of symptoms, supplemented by examination of the clinical records. Frequent use of reliever inhalers implies poor control, and intermittent requests for preventer treatment signals the need to address patients' perception of, and fears about, regular treatment. ${ }^{10}$ The occurrence of an acute exacerbation is evidence of poor control over a longer timeframe than the duration of current symptoms. ${ }^{31}$ A primary care clinician with access to patient records can easily check the number of courses of oral steroid required over the previous year. A 'one-off' peak expiratory flow (PEF) or spirometry reading taken in clinic is of limited value in assessing the control of a variable condition, though if the patient is well-controlled it can provide an up-to-date 'best' reading for use in action plans. Although few patients will maintain an accurate paper-based PEF diary on a daily basis, ${ }^{32,33}$ use of mobile technology may engage some patients with on-going PEF and symptom monitoring. ${ }^{34,35}$

Surveys have consistently shown unacceptably high levels of asthma morbidity. ${ }^{48}$ Trials demonstrate that by adopting a policy of 'zero tolerance' to symptoms, patients with asthma can achieve good control;;6 however, it remains unclear to what extent good control as defined by guidelines can be achieved in real-life practice. ${ }^{37}$ Patients will wish to balance the benefits of stepping up therapy until control is achieved against perceptions of, and preferences for, long-term treatment, and the practicalities of short consultations may restrict the time available to address all the diverse factors which result in poor control. ${ }^{37}$

\section{- Measures of morbidity}

Patients' perception of control may differ markedly from that based on objective assessment of symptoms, ${ }^{5,8}$ and clinicians over-estimate improvements in asthma control. ${ }^{6}$ This has given impetus to the development of morbidity scores, suitable for use in clinical practice, which can facilitate detection of poor control. A review of some asthma control tools is available on the web-site of the International Primary Care Respiratory Group. ${ }^{38,39}$ Common to all these tools is specific enquiry about the presence of symptoms, interference with activities and disturbance at night.

There are two short, well-validated questionnaires widely used in research which may be suitable for use in clinical practice. ${ }^{10,30}$ The Asthma Control Questionnaire ${ }^{40,41}$ uses five morbidity questions plus an optional measure of the forced expiratory volume in one second $\left(\mathrm{FEV}_{1}\right)$, has been tested for use in clinical practice, and a score of more than 1.5 indicates poor control. ${ }^{42}$ The Asthma Control Test uses similar morbidity questions but also includes a rating of overall control, with a score of 20 or more indicating good control. ${ }^{43,44}$ Both are available in a number of languages and have been validated for self-administration.

However, validity of questionnaires is determined under carefully controlled conditions, since the mode, circumstances and place of administration may affect the responses. ${ }^{45}$ By contrast, conditions of administration in routine clinical practice are likely to be very variable, with some practices arranging completion prior to the asthma review at home or in the waiting room, whilst others administer them formally in the consultation. Some clinicians may explain or paraphrase the questions to assist with completion. There is, therefore, a need to establish the value of such scores for assessing

\section{Table 2. The Royal College of Physicians three questions ${ }^{46}$.}

In the last month

1. Have you had difficulty sleeping because of asthma symptoms (including cough)?

2. Have you had your usual asthma symptoms during the day (cough, wheeze, chest tightness or breathlessness)?

3. Has your asthma interfered with your usual activities (eg housework, work, school, etc)? 
control in a range of normal clinical scenarios.

The 'Royal College of Physicians (RCP) three questions' represent a consensus UK view on a short symptom questionnaire, ${ }^{46}$ which correlates with the Asthma Control Questionnaire and is responsive to change. ${ }^{47} \mathrm{~A}$ refinement of the RCP three questions which scores the number of days in the previous week affected by symptoms has been suggested to improve discriminatory power. The questions (or very similar precursors of the 'RCP three questions') have been used successfully to target care, ${ }^{48}$ including use by postal questionnaire ${ }^{49}$ and during telephone reviews. ${ }^{50}$ Whilst occasional symptoms (e.g. on two or less days a week) may be acceptable, any nocturnal waking or activity limitation should be considered as less than well-controlled disease, and management should be adjusted accordingly. ${ }^{3,10}$

\section{Response to assessment and adjustment of management}

If control is good, a reminder of action to be taken if asthma deteriorates may be all that is necessary. However, if assessment of symptoms, taken in conjunction with the reported and recorded use of short-acting bronchodilators and any recent history of any acute attacks, suggests that control is not ideal, the reasons for this should be considered and addressed appropriately before increasing asthma therapy. ${ }^{10} \mathrm{~A}$ recent primary care review has considered the causes for poor control in detail. ${ }^{51}$ Here, we present $a$ summary of the key implications for routine practice:

- Reviewing the diagnosis

An increase in symptoms, or failure to respond to treatment, should lead to reconsideration of the diagnosis ${ }^{10,52}$ An unrecognised diagnosis (for example chronic obstructive pulmonary disease (COPD) in a smoker, gastro-oesophageal reflux as a trigger for cough, obesity as a cause of breathlessness), or the development of a co-morbid condition, may be responsible for apparent poor control..$^{52} \mathrm{~A}$ wide range of rare conditions in childhood may be initially misdiagnosed as asthma..$^{53}$

- Checking and correcting inhaler technique

Poor inhaler technique is a well documented problem which results in ineffective and wasteful use of therapy, and is an important cause of poor control. ${ }^{51-56}$ As few as a quarter of patients make no mistakes when using a pressurised metered-dose inhaler (pMDI), while just over a half can use dry powder inhalers, breath-actuated pMDI or pMDI with a spacer without errors. ${ }^{57}$ Provision of a spacer for use in an acute situation may improve effectiveness at a time when breathlessness makes usual pMDI technique more difficult.

Meta-analysis of the effect of teaching inhaler technique shows significant improvement after an educational intervention with a 'number needed to teach' (to achieve an 'ideal' technique) of 2.6 patients. ." $^{57}$ However, repeated training is required to maintain good technique. 55,56 Those unable to master or maintain good technique with one device should be offered an alternative. ${ }^{51}$ This has been specifically highlighted in children, where inadequate technique resulting either from poor training or from choosing a device poorly suited to the child - significantly reduces drug delivery to the lungs and results in poor asthma control. ${ }^{58}$

Practical training when a device is first prescribed, supported by review of inhaler technique at every asthma consultation (whether with a nurse, doctor, pharmacist or other healthcare professional) is good practice. ${ }^{3,10,55,56,58}$

\section{- Assessing adherence}

Adherence with regular preventative medication is known to be poor, and under-use should be considered when there is a failure to control asthma symptoms. ${ }^{59,60}$ Patients self-reporting and health care professional assessment both overestimate regular use of prophylactic medication. ${ }^{59,61,62}$ In primary care, repeat prescribing records provide an indication of adherence with prescribed asthma regimens. ${ }^{10}$

Simple, verbal and written instructions and information on asthma and its treatment for patients and carers may help to overcome unintentional non-adherence. ${ }^{10}$ Patents balance their perceived need for treatment against their concerns about taking a medication. ${ }^{51}$ Enquiry, based on a nonjudgemental assumption of non-adherence, can facilitate an open discussion of the rationale and potential benefits of regular therapy versus the disadvantages of taking a drug with (perceived or real) side effects, thus enabling the patient to reach an informed decision about concordance with clinical advice on the use of inhaled steroids.

\section{- Asking about, and treating rhinitis}

Rhinitis and asthma are common diseases which co-exist in $75-80 \%$ of patients ${ }^{52}$ and are associated with substantial cost to patients, employers and health care systems. The relationship between rhinitis and asthma is strongly supported by epidemiological, pathophysiological and clinical evidence. $^{63-71}$ Patients with co-existent asthma and rhinitis incur greater prescription drug costs and experience more general practitioner (GP) visits and hospitalisations for asthma than those with asthma alone..$^{72,73}$

Treatment of concomitant allergic rhinitis, particularly with intranasal steroids and/or leukotriene receptor antagonists, is associated with significant reductions in risk of emergency room treatment and hospitalisation for asthma. ${ }^{74-76}$ Rhinitis (including seasonal rhinitis) should therefore be sought as a co-morbidity in all patients with uncontrolled asthma and treated appropriately. ${ }^{52}$

- Assessing smoking status and offering cessation advice Smoking adversely affects asthma control. This may signal a diagnosis of COPD, either as a co-morbidity or because the COPD has been incorrectly diagnosed as asthma. Smoking also reduces 
the effectiveness of inhaled steroids. ${ }^{63,77,78}$ It is therefore important to enquire about smoking status and to offer cessation advice to patients with poorly controlled asthma. Persistent smokers may need relatively high doses of inhaled steroids. ${ }^{10}$

- Adjusting therapy according to evidence-based guidelines

After consideration of diagnosis, compliance, inhaler technique, smoking status, triggers and rhinitis, the identification of poor control should result in a step-up of treatment in accordance with the evidence-based advice of international or national guidelines. ${ }^{3,10}$ Discussion of the advantages and disadvantages of treatment options, and acknowledgement of patient preferences - i.e. whether to accept symptoms, or whether to accept a change or an increase in treatment such as a higher dose of inhaled steroids, an additional therapy, a combination inhaler instead of separate inhalers, an inhaled long-acting bronchodilator or an oral leukotriene receptor antagonist - is good consulting practice and would seem likely to optimise future concordance. ${ }^{79}$

Control should be maintained on the lowest possible dose and stepping down treatment is an important and frequentlyoverlooked step for patients who are consistently well controlled, especially in children who often 'grow out' of their asthma. ${ }^{3,10}$

\section{Exploring perceptions and supporting self-management}

- Guideline recommendations

International guidelines emphasise that "Patient education is the key to success of every aspect of asthma management and prevention", ${ }^{3}$ as many of the obstacles to achieving best control relate to misunderstanding of the condition, underestimation of the potential benefits of regular treatment, and exaggerated fears about side effects of asthma treatment. The UK national guideline includes the Grade A recommendation that "Patients with asthma should be offered selfmanagement education that should focus on individual needs, and be reinforced by a written action plan". ${ }^{10}$

The provision of self-management education, incorporating a written asthma action plan, can reduce hospitalisation, ${ }^{80}$ unscheduled consultations, time lost from work and nocturnal asthma, as well as improving self-efficacy and asthma-related quality of life..$^{16,81}$ Similar benefits have been shown in school age children, ${ }^{20}$ though an innovative approach may be required for pre-school children. ${ }^{81}$

Clear advice from a systematic review on the components of effective asthma action plans - i.e. written instructions, 23 action points triggered by symptoms or based on best peak flow, advice on increasing inhaled steroids and commencing oral steroids - is now available. ${ }^{82}$ Health professionals should tailor the self-management intervention to allow for patient preference (e.g. preferred degree of autonomy versus frequency of professional review; peak flow versus symptom monitoring) as well as the severity of asthma, risk of very severe attacks and the maintenance treatment plan. ${ }^{19}$

\section{- Implementation in primary care}

The challenge for primary care is that of implementing these evidence-based recommendations. Studies have shown consistently that provision of self-management education is poorly implemented in practice. ${ }^{8,83,84}$ Some of the recognised barriers, such as time and resources, are practical issues which need to be addressed when planning routine care for people with asthma. ${ }^{85,86}$ Confusion about details of action plans (such as the relevance of increasing inhaled steroids) are a further barrier. ${ }^{87}$ Despite the growing body of evidence from primary care, ${ }^{88.92}$ there is scepticism about whether the evidence applies to the relatively low risk mild patients in whom benefit is harder to demonstrate. ${ }^{84}$ More fundamentally, provision of asthma action plans is often perceived as an optional task delegated to a nurse educator. ${ }^{80}$ Recognition that self-care and professional care are inextricably linked as complementary aspects of the management of all people with long-term conditions - as illustrated in the framework for monitoring and self-monitoring (see Figure 2$)^{17}$ - may be the conceptual key that will help unlock implementation.

A systematic review of the implementation of asthma action plans highlighted the importance of this interrelationship between the facilitation of regular, structured review and the provision of self-management education. ${ }^{93} \mathrm{All}$ three primary care studies in this review demonstrated increased ownership of asthma action plans, 92,94,95 and showed a consistent trend to improved clinical outcomes, though the only significant benefits were a reduction in episodes of 'speech limiting wheeze', ${ }^{92}$ and night time waking. ${ }^{94}$ Similarly, within managed care programmes, nurse-led telephonebased reviews incorporating self-management education supported by written information can increase the use of inhaled steroids. ${ }^{96,97}$ This inter-relationship is encompassed in international guidelines as the concept of 'guided selfmanagement'. ${ }^{3}$

\section{Ensuring access to professional advice}

Patients value flexible access to professional advice in order to support self-care, ${ }^{29,98}$ but not all patients are willing to attend a pre-arranged appointment for a regular review. ${ }^{83,99}$ Repeat prescribing arrangements should aim to be sufficiently flexible to enable patients to order more inhalers promptly when needed, but should include checks to ensure that those patients requesting reliever inhalers frequently are reminded to arrange a review.

There is now evidence to inform the appropriate role of telephone asthma reviews. ${ }^{10,50,101,102}$ Telephone asthma reviews 
Table 3. A suggested service model for provision of asthma reviews.

- $\quad$ Ensure adequate and updated specialist training of clinicians.

- Consider strategies for maximising access - e.g flexible timing of 'clinics', offering a choice of mode of review, expecting that most patients will make a choice appropriate to the severity of their asthma.

- $\quad$ Set up a register and devise a recall system using a range of reminders (verbal, postal, telephone, e-mail, SMS). Consider opportunistic phone calls to non-attenders.

- $\quad$ Ask standard morbidity questions to enable objective assessment of control and tailor the review (both in content and mode of delivery) appropriate to the needs of the patient.

- $\quad$ Adopt a policy of 'zero tolerance' of symptoms, addressing the potential reasons for poor control and recommending stepping up treatment as appropriate.

- $\quad$ Prioritise guided self-management and the provision of personal asthma action plans, using every opportunity to review, revise, and refine the plan with the patient.

- $\quad$ Audit the asthma review service, ideally focusing not only on process, but also on patient outcomes.

increase the proportion of patients reviewed without loss of clinical effectiveness, ${ }^{100}$ though patients whose asthma is causing concern prefer a face-to-face review. ${ }^{101}$ Asking standard morbidity questions by telephone can identify those who should be invited for a face-to-face review whilst offering a convenient telephone option to those currently under good control. ${ }^{50}$ The provision of a telephone asthma review option within routine practice showed that opportunistic telephone calls could provide consultations to non-responders who would otherwise not have had a review. ${ }^{102}$ A suggested model of care incorporating this evidence is given in Table 3 .

\section{Ensuring quality Appropriate training}

Asthma reviews should be undertaken by healthcare professionals with appropriate training to enable them not only to assess control but also to adjust treatment as necessary. ${ }^{20} \mathrm{In}$ the UK, this is frequently an experienced practice nurse, though a survey published in 2007 highlighted that $20 \%$ of nurses did not have any specialist asthma training. ${ }^{103}$ Whilst guidelines (and clinical governance) might recommend that at least one member of the primary care team has specialist respiratory training, this raises concerns about the potential deskilling of other members of the team. ${ }^{84}$ Poorly defined interprofessional roles and inadequate communication between colleagues can act as barriers to the implementation of guideline recommendations, ${ }^{86}$ an issue of particular importance in the context of guided self-management. Although a specialist clinician may initiate education, it is incumbent on all members of the team to provide the on-going, consistent support for guided self-management. ${ }^{104}$ Multi-disciplinary education and support for professionals was a core component of the successful Finnish programme. ${ }^{21}$

\section{Audit and standards}

A systematic review of 118 randomised controlled trials spanning a range of countries, professionals and disease areas concluded that audit and feedback can be moderately effective at improving professional practice. ${ }^{105}$ The process of asthma reviews, particularly when the consultations are recorded on computer templates, offers ready opportunities for repeated audit cycles. However, detailing and auditing all the possible functions of an asthma review, whilst potentially improving process, risks automating the consultation and making it less responsive to individual patient needs. The UK Quality and Outcomes Framework (QOF) - a 'pay for performance' scheme which was introduced as part of the UK General Medical Services Contract in 2004 and which rewards practices for achieving pre-determined standards of care for a range of long-term conditions ${ }^{16}$ - recognised this potential risk, and the approach adopted was to reward the 'provision of an asthma review' recorded as a single coded entry in the computerised clinical records. ${ }^{106}$ Concerns remain about the quality of the review represented by this 'tick box', though serial detailed audits in 60 representative practices showed significant progress in assessing control by the recording of specific symptoms, and checking inhaler technique as part of the review. ${ }^{107}$ Disappointingly, despite uniformly high achievement in the process measures for $\mathrm{QOF}^{108}$ the proportion of well-controlled patients varies considerably between practices. ${ }^{109}$

\section{Conclusion}

Too many of the 300 million people around the world living with asthma are coping on a daily basis with a variable condition that significantly affects their quality of life, despite the existence of treatment which could substantially improve their symptoms. At the core of a routine review is the opportunity to identify patients with sub-optimal control and (for both patients and professionals) the need to adopt an approach of 'zero tolerance' to symptoms. Recognition of the inter-relationship of professional reviews and patient self- 
management underpins the partnership as future management strategies are negotiated.

\section{Funding}

No direct funding. HP is supported by a Primary Care Research Career Award from the Chief Scientist's Office, Scottish Government.

\section{Conflict of interest declarations}

None known.

\section{Acknowledgements}

This paper builds on work on asthma reviews, commissioned by the Primary Care Respiratory Society UK (PCRS-UK) formerly known as the General Practice Airways Group (GPIAG), together with the British Thoracic Society, Education for Health and Asthma UK, in preparation for a joint submission to the UK QOF review panel. We thank Professor Chris Griffiths for his helpful comments on an earlier draft.

\section{Contributorship}

$\mathrm{HP}, \mathrm{BW}, J \mathrm{~L}, J V, \mathrm{MF}$, and RR prepared the original QOF submission and all the authors contributed to the preparation of this discussion paper.

\section{References}

1. Masoli M, Fabian D, Holt S, Beasley R. The Global Burden of Asthma. Global Initiative for Asthma. 2003. http://www.ginasthma.com

2. The Information Centre. Quality and Outcome Framework http://www.ic.nhs.uk/servicesnew/qof06/

3. Global Initiative for Asthma (GINA) Global Strategy for Asthma Management and Prevention, 2007. Available from: http://www.ginasthma.org

4. Smith NM. The 'Needs of people with asthma' survey and initial presentation of the data. Asthma J 2000;5:133-7.

5. Rabe KF, Vermeire PA, Soriano JB, Maier WC. Clinical management of asthma in 1999: the Asthma Insights and Reality in Europe (AIRE) study. Eur Respir J 2000; 16:802-07

6. Juniper EF, Chauhan A, Neville E, et al. Clinicians tend to overestimate improvements in asthma control: an unexpected observation. Prim Care Resp J 2004;13:181-4. http://dx.doi.org/10.1016/j.pcrj.2004.04.003

7. Asthma UK. Everyday asthma out of control. Asthma UK July 2004. http://www.asthma.org.uk/news/pdf/everydayasthma.pdf

8. Haughney J, Barnes G, Partridge M, Cleland J. The Living \& Breathing study: a study of patients' views of asthma and its treatment. Prim Care Resp J 2004; 13:28-35. http://dx.doi.org/10.1016/j.pcrj.2003.11.007

9. National Asthma Panel. Data from Health Survey for England 2001, Joint Health Surveys Unit, 2003, The Scottish Health Survey 1998, Joint Health Surveys Unit, 2000, Census 2001 (Office for National Statistics). Asthma UK. 2006

10. British Thoracic Society-Scottish Intercollegiate Guideline Network. British Guideline on the Management of Asthma. Thorax 2008;63(Suppl 4):1-121. http://www.brit-thoracic.org.uk and http://www.sign.ac.uk

11. Jones A, Fay JK. Primary care based clinics for asthma. Cochrane Database of Systematic Reviews 2002, Issue 1. Art. No.: CD003533. DOI: 10.1002/14651858.CD003533

12. Feder G, Griffiths C, Highton C, Eldridge S, Spence M, Southgate L. Do clinical guidelines introduced with practice based education improve care of asthmatic and diabetic patients? A randomised controlled trial in general practices in east London. BMJ 1995;311:1473-8.

13. Charlton I, Charlton G, Broomfield J, Mullee M. Audit of the effect of a nurse run asthma clinic on workload and patient morbidity in a general practice. $\mathrm{Br} J$ Gen Pract 1991;41:227-31.

14. Glasgow NJ, Ponsonby A-L, Yates R, Beilby J, Dugdale P. Proactive asthma care in childhood: general practice based randomised controlled trial. BMJ 2003; 327:659-63. http://dx.doi.org/10.1136/bmj.327.7416.659
15. Griffiths C, Foster G, Barnes N, et al. Specialist nurse intervention to reduce unscheduled asthma care in a deprived multiethnic area: the east London randomised control trial for high risk asthma. BMJ 2004;328:144-7. http://dx.doi.org/10.1136/bmj.37950.784444.EE

16. NHS Confederation, British Medical Association New GMS Contract 2003: investing in general practice. London. March 2003

17. Glasziou P, Irwig L, Mant D. Monitoring in chronic disease: a rational approach. BMJ 2005;330:644-8. http://dx.doi.org/10.1136/bmj.330.7492.644

18. Gibson PG, Powell $H$, Wilson $A$, et al. Self-management education and regular practitioner review for adults with asthma. Cochrane Database of Systematic Reviews 2002, Issue 3. Art. No.: CD001117. http://dx.doi.org/ 10.1002/14651858.CD001117

19. Powell H, Gibson PG. Options for self-management education for adults with asthma. Cochrane Database of Systematic Reviews 2002, Issue 3. Art. No.: CD004107. http://dx.doi.org/10.1002/14651858.CD004107

20. Wolf FM, Guevara JP, Grum CM, Clark NM, Cates CJ. Educational interventions for asthma in children. Cochrane Database of Systematic Reviews 2002, Issue 4. Art. No.: CD000326. http://dx.doi.org/10.1002/14651858.CD000326.

21. Haahtela T, Tuomisto LE, Pietinalho A, et al. A 10 year asthma programme in Finland: major change for the better. Thorax 2006;61:663-70. http://dx.doi.org/10.1136/thx.2005.055699

22. National Asthma Council of Australia. Asthma Management Handbook 2006. National Asthma Council Australia. Melbourne 2006 http://www.nationalasthma.org.au

23. World Health Organisation. Innovative care for chronic conditions: building blocks for action. Geneva; 2002. http://www.who.int

24. Secretary of State for Health. Our health, our care, our say: a new direction for community services. The Stationery Office. London 2006.

25. Epping-Jordan JE, Pruitt SD, Bengoa R, Wagner EH. Improving the quality of health care for chronic conditions. Qual Saf Health Care 2004;13:299-305. http://dx.doi.org/10.1136/qshc.2004.010744

26. Long Term Conditions Team Primary Care, Improving care, improving lives. Department of Health. 2005

27. Department of Health. Improving chronic disease management. March 2004 available from http://www.dh.gov.uk

28. Degeling $\mathrm{P}, \mathrm{Close} \mathrm{H}$, Degeling $\mathrm{D}$. Re-thinking long term conditions: A report on the development and implementation of co-produced, year-based integrated care pathways to improve service provision to people with long term conditions. Durham: Centre for Clinical Management Development, 2006

29. Kielmann T, Huby G, Powell A, et al. From support to boundary: a qualitative study of the border between self care and professional care. Pat Ed Counsel 2009, http://dx.doi.org/10.1016/j.pec.2009.07.015

30. Reddel HK, Taylor DR, Bateman ED, et al. An Official American Thoracic Society/European Respiratory Society Statement: Asthma Control and Exacerbations: Standardizing Endpoints for Clinical Asthma Trials and Clinica Practice. Am J Respir Crit Care Med 2009;180:59-99. http://dx.doi.org/10.1164/rccm.200801-060ST

31. Thomas M, Kay S, Pike J, et al. The Asthma Control Test TM (ACT) as a predictor of GINA guideline-defined asthma control: analysis of a multinational cross-sectional survey. Prim Care Resp J 2009;18:41-9. http://dx.doi.org/10.4104/pcrj.2009.00010.

32. Yoos HL, Kitznian H, MeMullen A, Henderson C, Sidora K. Symptom monitoring in childhood asthma: a randomized clinical trial comparing peak expiratory flow rate with symptom monitoring. Ann Allergy Asthma Immunol 2002;88:283-91.

33. Verschelden P, Cartier A, L'Archeveque J, Trudeau C, Malo JL. Compliance with and accuracy of daily self-assessment of peak expiratory flows (PEF) in asthmatic subjects over a three month period. Eur Respir J 1996;9:880-5.

34. Reddel HK, Toelle BG, Marks GB, Ware SI, Jenkins CR, Woolcock AJ. Analysis of adherence to peak flow monitoring when recording of data is electronic. 
BMJ 2002;324:146-7. http://dx.doi.org/10.1136/bmj.324.7330.146

35. Ryan D, Cobern W, Wheeler J, Price D, Tarassenko J. Mobile phone technology in the management of asthma. Telemed Telecare 2005;11(Suppl1):43-6. http://dx.doi.org/10.1258/1357633054461714

36. Bateman ED, Boushey HA, Bousquet J, et al. Can guideline-defined asthma control be achieved? The Gaining Optimal Asthma ControL study. Am J Respir Crit Care Med 2004;170:836-44. http://dx.doi.org/10.1164/rccm.2004010330C

37. Levy ML. Guideline-defined asthma control: a challenge for primary care. Eur Respir J 2008;31:229-31. http://dx.doi.org/10.1183/09031936.00157507

38. International Primary Care Respiratory Group. The IPCRG Users' Guide to currently available asthma control tools. IPCRG 2006. http://www.theipcrg.org/

39. Horne R, Price D, Cleland J, et al. Can asthma control be improved by understanding the patients perspective? BMC Pulm Med 2007;7:8. http://dx.doi.org/10.1186/1471-2466-7-8

40. Juniper EF, O'Byrne PM, Guyatt GH, Ferrie PJ, King DR. Development and validation of a questionnaire to measure asthma control. Eur Respir J 1999; 14:902-07.

41. Juniper EF, Svensson K, Mork AC, Stahl E. Measurement properties and interpretation of three shortened versions of the asthma control questionnaire. Respir Med 2005;99:553-8. http://dx.doi.org/10.1016/j.rmed.2004.10.008

42. Juniper EF, Bousquet J, Abetz L, Bateman ED. Identifying 'well-controlled' and 'not well-controlled' asthma using the Asthma Control Questionnaire. Respir Med 2006;100:616-21. http://dx.doi.org/10.1016/j.rmed.2005.08.012

43. Nathan RA, Sorkness CA, Kosinski M, et al. Development of the asthma control test: a survey for assessing asthma control. J Allergy Clin Immunol 2004;113:59-65. http://dx.doi.org/10.1016/j.jaci.2003.09.008

44. Schatz M, Sorkness CA, Li JT, et al. Asthma Control Test: reliability, validity, and responsiveness in patients not previously followed by asthma specialists. J Allergy Clin Immunol 2006;117:549-56. http://dx.doi.org/10.1016/ j.jaci.2006.01.011

45. Fitzpatrick R, Davey C, Buxton MJ, Jones DR. Evaluating patient-based outcome measures for use in clinical trials. Health Technol Assess 1998;2(14):1-74.

46. Pearson MG, Bucknall CE, editors. Measuring clinical outcome in asthma : a patient-focused approach. London: Royal College of Physicians; 1999.

47. Thomas M, Gruffydd-Jones K, Stonham C, Ward S, Macfarlane T. Assessing asthma control in routine clinical practice: use of the Royal College of Physicians '3 Questions'. Prim Care Resp J 2009;18:83-8. http://dx.doi.org/10.3132/pcrj.2008.00045

48. Jones KP, Bain DJG, Middleton M, Mullee MA. Correlates of asthma morbidity in primary care. BMJ 1992;304:361-4. http://dx.doi.org/10.1136/ bmj.304.6823.361

49. Jones KP, Charlton IH, Middleton M, Preece WJ, Hill AP. Targeting asthma care in general practice using a morbidity index. BMJ 1992;304:1353-9. http://dx.doi.org/10.1136/bmj.304.6838.1353

50. Gruffydd-Jones K, Hollinghurst S, Ward S, Taylor G. Targeted routine asthma care in general using telephone triage. Br J Gen Pract 2005;55:918-23.

51. Haughney J, Price D, Kaplan A, et al. Achieving asthma control in practice: Understanding the reasons for poor control. Respir Med 2008;102:1681-93. http://dx.doi.org/10.1016/j.rmed.2008.08.003

52. Thomas M, Price D. Impact of co-morbidities on asthma. Expert Rev Clin Immuno/ 2008;4:731-42. http://dx.doi.org/10.1586/1744666X.4.6.731

53. Keeley DJ Silverman M. Are we too ready to diagnose asthma in children? Thorax 1999;54:625-8. http://dx.doi.org/10.1136/thx.54.7.625

54. Giraud V, Roche N. Misuse of corticosteroid metered-dose inhaler is associated with decreased asthma stability. Eur Respir J 2002;19:246-51. http://dx.doi.org/10.1183/09031936.02.00218402

55. Virchow JC, Crompton GK, Dal Negro R et al. Importance of inhaler devices in the management of airway disease. Respir Med 2008;102:10-19. http://dx.doi.org/10.1016/j.rmed.2007.07.031

56. Broeders MEAC, Sanchis J, Levy ML, Crompton GK, Dekhuijzen PNR, on behalf of the ADMIT Working Group. The ADMIT series - Issues in Inhalation Therapy. 2) Improving technique and clinical effectiveness. Prim Care Resp J 2009;18:7682. http://dx.doi.org/10.4104/pcrj.2009.00025

57. Brocklebank D, Ram F, Wright J, et al. Comparison of the effectiveness of inhaler devices in asthma and chronic obstructive airways disease: a systematic review of the literature. Health Technol Assess 2001;5:1-149.

58. National Institute for Clinical Excellence. Inhaler devices for routine treatment of chronic asthma in older children (aged 5-15 years). March 2002. www.nice.org.uk

59. Cochrane MG, Bala MV, Downs KE, Mauskopf J, Ben-Joseph RH. Inhaled corticosteroids for asthma therapy: patient compliance, devices, and inhalation technique. Chest 2000;117:542-50. http://dx.doi.org/10.1378/ chest.117.2.542

60. Jonasson G, Carlsen KH, Sodal A, Jonasson C, Mowinckel P. Patient compliance in a clinical trial with inhaled budesonide in children with mild asthma. Eur Respir J 1999;14:150-4.

61. Berg J, Dunbar-Jacob J, Sereika SM. An evaluation of a self-management program for adults with asthma. Clin Nurs Res 1997;6:225-38. http://dx.doi.org/10.1177/105477389700600304

62. Braunstein GL, Trinquet G, Harper AE, and the Compliance Working Group. Compliance with nedocromil sodium and a nedocromil sodium/salbutamol combination. Eur Respir J 1996;9:893-8.

63. Leynaert B, Bousquet J, Neukirch C, Liard R, Neukirch F. Perennial rhinitis: an independent risk factor for asthma in non-atopic subjects: results from the European Community Respiratory Health Survey. J Allergy Clin Immunol 1999; $30: 1-4$.

64. Walker S, Sheikh A. Self-reported rhinitis is a significant problem for patients with asthma: results from a national (UK) survey. Prim Care Resp J 2005;14: 83-7. http://dx.doi.org/10.1016/j.pcrj.2004.10.005

65. Rhinitis and its Impact on Asthma (ARIA) and the WHO. Allergic Rhinitis and its Impact on Asthma. J Allergy Clin Immunol 2001;108:S147-336.

66. Sibbald B. Epidemiology of seasonal and perennial rhinitis: clinical presentation and clinical history. Thorax 1991;46:895-901. http://dx.doi.org/10.1136/ thx.46.12.895

67. Yawn BP, Yunginger JW, Wollan PC, Reed CE, Silverstein MD, Harris AG. Allergic rhinitis in Rochester, Minnesota residents with asthma: frequency and impact on health care charges. J Allergy Clin Immunol 1999;103:54-9. http://dx.doi.org/10.1016/S0091-6749(99)70525-7

68. Neukirch F, Pin I, Knani J, et al. Prevalence of asthma and asthma-like symptoms in three French cities. Resp Med 1995;89:685-92.

69. Wright AL, Holberg CJ, Halonen M, Martinez FD, Morgan W, Taussig LM. Epidemiology of physician-diagnosed allergic rhinitis in childhood. Pediatrics 1994;94:895-901. http://dx.doi.org/10.1016/0954-6111(95)90136-1

70. Huovinen E, Kaprio J, Laitinen LA, Koskenvuo M. Incidence and prevalence of asthma among Finnish men and women of the Finnish Twin Cohort from 1975 to 1990, and their relation to hay fever and chronic bronchitis. Chest 1999;115:928-36. http://dx.doi.org/10.1378/chest.115.4.928

71. Greisner W. Co-existence of asthma and allergic rhinitis: a 23-year follow-up study of college students. Allergy Asthma Proceedings 1998;19:185-8. http://dx.doi.org/10.2500/108854198778557836

72. Thomas M, Kocevar VS, Zhang Q, Yin DD, Price D. Asthma-Related Health Care Resource Use Among Asthmatic Children With and Without Concomitant Allergic Rhinitis. Pediatrics 2005;115:129-34.

73. Price D, Zhang Q, Kocevar VS, Yin DD, Thomas M. Effect of a concomitant diagnosis of allergic rhinitis on asthma-related health care use by adults. Clin Exp Allergy 2005;35:282-7. http://dx.doi.org/10.1111/j.1365-2222. 2005.02182.x

74. Corren J, Manning B, Thompson S, Hennessy S, Strom B. Rhinitis therapy and 
the prevention of hospital care for asthma: A case-control study. J Allergy Clin Immunol 2004;113:415-19. http://dx.doi.org/10.1016/j.jaci.2003.11.034

75. Adams RJ, Fuhlbrigge AL, Finkelstein JA, Weiss ST. Intranasal steroids and the risk of emergency department visits for asthma. J Allergy Clin Immunol 2002; 109:636-42. http://dx.doi.org/10.1067/mai.2002.123237

76. Price DB, Swern A, Tozzi CA, Philip G, Polos P. Effect of montelukast on lung function in asthma patients with allergic rhinitis: analysis from the COMPACT trial. Allergy 2006:61:737-42. http://dx.doi.org/10.1111/j.13989995.2006.01007.x

77. Thomson NC, Chaudhuri R, Livingston E. Asthma and cigarette smoking. Eur Respir J 2004;24:822-33. http://dx.doi.org/10.1183/09031936.04.00039004

78. Chaudhuri R, Livingston E, McMahon AD, et al. Effects of smoking cessation on lung function and airway inflammation in smokers with asthma. Am J Respir Crit Care Med 2006;174:127-33. http://dx.doi.org/10.1164/rccm.200510$15890 C$

79. Kurtz S, Silverman J. The Calgary-Cambridge Observation Guides: an aid to defining the curriculum and organising the teaching in Communication Training Programmes. Med Education 1996;30:83-9. http://dx.doi.org/ 10.1111/j.1365-2923.1996.tb00724.x

80. Adams RJ, Smith BJ, Ruffin RE. Factors associated with hospital admissions and repeat emergency department visits for adults with asthma. Thorax 2000, 55:566-73. http://dx.doi.org/10.1136/thorax.55.7.566

81. Stevens CA, Wessledine LJ, Couriel JM, Dyer AJ, Osman LM, Silverman M. Parental education and guided self management of asthma and wheezing in the pre-school child: a randomised controlled trial. Thorax 2002;57:39-44. http://dx.doi.org/10.1136/thorax.57.1.39

82. Gibson PG, Powell H. Written action plans for asthma: an evidence-based review of the key components. Thorax 2004;59:94-9. http://dx.doi.org/ 10.1136/thorax.2003.011858

83. Price D, Wolfe S. Delivery of asthma care: patient's use of and views on healthcare services, as determined from a nationwide interview survey. Asthma J 2000;5:141-4.

84. Wiener-Ogilvie S, Pinnock H, Huby G, Sheikh A, Partridge MR, Gillies J. Do practices comply with key recommendations of the British Asthma Guideline, and if not, why not? Prim Care Resp I 2007; 16:369-77. http://dx.doi.org/10.3132/pcrj.2007.00074

85. Thoonen BPA, Jones KP, van Rooij HA, et al. Self-treatment of asthma: possibilities and perspectives from the practitioner's point of view. Fam Practice 1999;16:117-22. http://dx.doi.org/10.1093/fampra/16.2.117

86. Weiner-Ogilvie S, Huby G, Pinnock H, Gillies J, Sheikh A. Practice organisational characteristics can impact on compliance with the BTS/SIGN asthma guideline: qualitative comparative case study in primary care. BMC Family Practice 2008;9:32. http://dx.doi.org/10.1186/1471-2296-9-32

87. Levy M, Pinnock H, Crockett A, Haughney J. Clinical Information Analyst (ATTRACT). BTS/SIGN Guidelines - Query for Committee. Prim Care Resp J 2003;12:72-3.

88. Hayward SA, Jordan M, Golden G, Levy M. A randomised controlled evaluation of asthma self-management in general practice. Prim Care Resp J (formerly Asthma in Gen Practice) 1996:4:11-13.

89. Moudgil $H$, Marshall T, Honeybourne D. Asthma education and quality of life in the community: a randomised controlled study to evaluate the impact on white European and Indian subcontinent ethnic groups from socioeconomically deprived areas in Birmingham, UK. Thorax 2000;55:177-83. http://dx.doi.org/10.1136/thorax.55.3.177

90. Guendelman S, Meade K, Benson M, Chen Y, Samuels S. Improving asthma outcomes and self-management behaviors of inner-city children. Arch Pediatr Adolesc Med 2002;156:114-20.

91. Thoonen BPA, Schermer TRJ, van den Boom G, et al. Self-management of asthma in general practice, asthma control and quality of life: a randomised controlled trial. Thorax 2003;58:30-6. http://dx.doi.org/10.1136/ thorax.58.1.30

92. Glasgow NJ, Ponsonby A-L, Yates R, Beilby J, Dugdale P. Proactive asthma care in childhood: general practice based randomised controlled trial. BMJ 2003; 327:659-65. doi:10.1136/bmj.327.7416.659

93. Ring N, Malcolm C, Wyke S, et al. Promoting the use of Personal Asthma Action Plans: a systematic review. Prim Care Resp J 2007;16:271-83. http://dx.doi.org/10.3132/pcrj.2007.00049

94. Heard AR, Richards IJ, Alpers JH, Pilotto LS, Smith BJ, Black JA. Randomised controlled trial of general practice based asthma clinics. Med J Aust 1999; 171:68-71.

95. Kemple T, Rogers C. A mailed personalised self-management plan improves attendance and increases patients' understanding of asthma. Prim Care Respir J 2003;12:110-14.

96. Delaronde S, Peruccio DL, Bauer BJ. Improving asthma treatment in a managed care population. Am J Managed Care 2005;11:361-8.

97. Feifer RA, Verbrugge RR, Khalid M, Levin R, O'Keefe GB, Aubert RE. Improvements in asthma pharmacotherapy and self-management: An example of a population-based disease management program. Dis Manage Health Outcomes 2004;12:93-102. http://dx.doi.org/10.2165/00115677-20041202000003

98. Kennedy A, Rogers A, Bower P. Support for self care for patients with chronic disease. BMJ 2007;335:968-70. http://dx.doi.org/10.1136/ bmj.39372.540903.94

99. Gruffydd-Jones K, Nicholson I, Best L, Connell E. Why don't patients attend the asthma clinic? Prim Care Resp J (formerly Asthma in Gen Pract) 1999;7:36-8.

100. Pinnock H, Bawden R, Proctor $S$, et al. Accessibility, acceptability and effectiveness of telephone reviews for asthma in primary care: randomised controlled trial. BMJ 2003;326:477-9. http://dx.doi.org/10.1136/ bmj.326.7387.477

101. Pinnock H, Snellgrove C, Madden V, Sheikh A. Telephone or surgery asthma reviews? Preferences of participants in a primary care randomised controlled trial. Prim Care Resp J 2005;14:42-6. http://dx.doi.org/10.1016/ j.pcrj.2004.10.002

102. Pinnock H, Adlem L, Gaskin S, Harris J, Snellgrove C, Sheikh A. Accessibility, clinical effectiveness and practice costs of providing a telephone option for routine asthma reviews: controlled implementation study. Br J Gen Pract 2007; 57:714-22.

103. Upton J, Madoc-Sutton H, Sheikh A, Frank TL, Walker S, Fletcher M. National survey on the roles and training of primary care respiratory nurses in the UK in 2006: are we making progress? Prim Care Resp J 2007;16:284-90. http://dx.doi.org/10.3132/pcrj.2007.00068

104. Cabana MD, Le TT. Challenges in asthma patient education. J Allergy Clin Immunol 2005;115:1225-7. http://dx.doi.org/10.1016/j.jaci.2005.03.004

105. Jamtvedt G, Young JM, Kristoffersen DT, O'Brien MA, Oxman AD. Audit and feedback: effects on professional practice and health care outcomes. Cochrane Database of Systematic Reviews 2006, Issue 2. Art. No.: CD000259. http://dx.doi.org/10.1002/14651858.CD000259.pub2

106. Roland M. Linking Physicians' Pay to the Quality of Care - A Major Experiment in the United Kingdom. N Engl J Med 2004;351:1448-54. http://dx.doi.org/ 10.1056/NEJMhpr041294

107. Campbell S, Reeves D, Kontopantelis E, Middleton E, Sibbald B, Roland M. Quality of Primary Care in England with the Introduction of Pay for Performance. N Engl J Med 2007;357:181-90. http://dx.doi.org/10.1056/ NEJMsr065990

108. Doran T, Fullwood C, Gravelle H, et al. Pay-for-Performance Programs in Family Practices in the United Kingdom. N Engl J Med 2006;355:375-84. http://dx.doi.org/10.1056/NEJMsa055505

109. Price D, Horne R, Ryan D, Freeman D, Lee A. Large variations in asthma control between UK general practices participating in the asthma control, concordance and tolerance (ACCT) Initiative. Prim Care Resp J 2006;15:206 (ABS74) 